\title{
Epithelial Cells with Vacuoles Containing 54,000 Dalton Sialoglycoprotein in the Mouse Epididymal Duct*
}

\author{
Kiyotaka Toshimori, Sanae ARAKI and Chikayoshi ŌURA \\ Department of Anatomy, Miyazaki Medical College, Miyazaki, Japan \\ Received September 22, 1989 ; revised manuscript received March 1, 1990
}

\begin{abstract}
Summary. Epididymal ligation in the mouse induced unusual cells, called peculiar pale epithelial cells (hereafter, pale cells), specifically in the epithelium of the corpus epididymidis (ABE et al., 1982a, b). These pale cells had vacuoles with long microvilli on their inner surface. In this study, we found that the vacuoles of the pale cells occurred in normal mice and contained epididymal specific glycoprotein, sialoglycoprotein of $\mathbf{5 4 , 0 0 0}$ dalton (SGP54). This was elucidated by indirect immunofluorescence and avidin biotin complex techniques using monoclonal antibody $\mathrm{T} 21$ which specifically recognizes SGP54. These immunoreactive pale cells occurred in the distal caput and proximal corpus of the epididymidis. The relationship between the pale cell and SGP54 is discussed.
\end{abstract}

In mammals, the epididymal duct forms the caput (head), corpus (body) and cauda (tail) of the epididymis, and the epithelium of the duct consists of a large number of principal cells with long microvilli (stereocilia) on the luminal surface and small numbers of clear cells with foamy cytoplasm. The epithelial cells secrete a variety of substances into the lumen, allowing regional differences in the composition of luminal materials along the duct (FLICKINGER, 1981; JONES, 1987; reviewed by ROBAIRE and HERMO, 1988). Among these substances, specific epididymal glycoproteins have been attracted much attention for the fact that during passage through the duct, spermatozoa are believed to interact with the glycoproteins and maturate to obtain fertilizing ability and forward motility (ORGEBIN-CRIST, 1967, 1975; BED-
FORD, 1975; ACOTT and HOSKINS, 1978; VOGLMAYR et al., 1980, 1985; BROOKS, 1983; OLSON and ORGEBINCRIST, 1982; KOPECNY et al., 1984; KLINEFELTER and HAMILTON, 1985; MOORE and HARTMAN, 1986; MOORE et al., 1986; SMITH et al., 1986; ISAHAKIA, 1989).

Recently, the authers established a cell line producing a monoclonal antibody-T21-which specifically recognizes an antigen on mature spermatozoa in the mouse epididymis (TOSHIMORI and EDDY, 1985). The antigen is a sialoglycoprotein of 54,000 dalton (SGP54); immunohistochemistry for this glycoprotein revealed that this is distributed in the lumen of the epididymal duct in the body and tail of the epididymis (TOSHIMORI et al., 1988, 1990). During a series of immunohistochemical studies using T21, we found a number of unusual immunoreactive epithelial cells with vacuoles containing T21-reactive material in the epithelium of the epididymal duct.

The aim of this report is to describe the relationship between SGP54 and the pale cells which occur in the normal mouse epididymis. The epididymis was divided into five segments according to the classification by TAKANO (1980) and ABE et al. (1982a, b): Segments I, II and III constituting the head of the epididymis, Segment IV the body, and Segment V the tail.

\section{MATERIALS AND METHODS}

\section{Animals}

A total of 15 ICR, CD-1, and ddY mice were used at 8-16 weeks of age.

*This study was supported by the Japanese Ministry of Education, Science, and Culture (Grant-in-aid for general scientific research No. 62570011 to K. T., No. 01570014 to C. O., and grant-in-aid for the encouragement of young scientists No. 63770022 to S. A.). 


\section{Immunohistochemistry}

The epididymides were fixed with Bouin's fixative perfused through the thoracic aorta. The fixed organs were removed and placed in Bouin's fixative overnight, cooled in a shaker, and then embedded in paraffin, and cut at $6-10 \mu \mathrm{m}$. The sections were deparaffinized for indirect immunofluorescence (IIF) and avidin-biotin complex (ABC) immunohistochemistry. The staining procedures for IIF and $\mathrm{ABC}$ have been previously reported (TOSHIMORI et al., 1988, 1990). Observation was done with a Zeiss epifluorescence microscope for IIF and phase contrast, and with a Nikon Optiphot light microscope for Nomarsky (diffraction interference contrast) and plain bright field observation for $\mathrm{ABC}$.

\section{Electron microscopy}

Several epididymides were fixed with $2.5 \%$ glutaraldehyde in $0.1 \mathrm{M}$ cacodylate buffer ( $\mathrm{pH} 7.4$ ) by perfusion as above, followed with immersion for $2 \mathrm{~h}$ to overnight, shaken on ice, postfixed with $2 \%$ osmic acid in the same buffer for $2 \mathrm{~h}$, shaken on ice, dehydrated and embedded in Epon 812 resin, and ultrathin
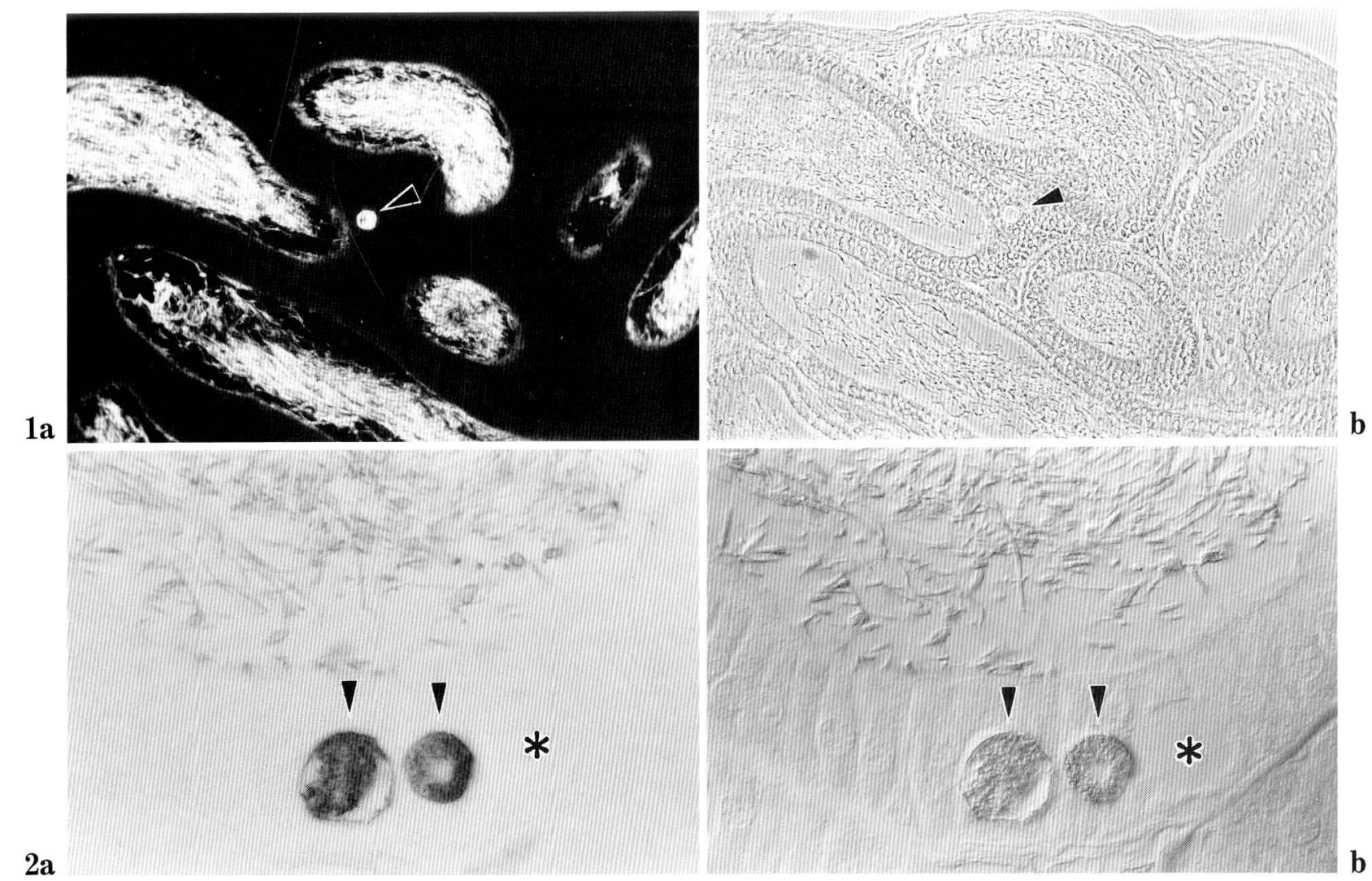

Fig. 1. Epididymal duct of proximal Segment IV. a. Indirect immunofluorescence image. b. Phase contrast image. A vacuole in the peculiar epithelial cell shows a strong immunoreaction (arrowhead) in addition to luminal spermatozoa and stereocilia. $\times 310$

Fig. 2. Higher magnification of epididymal duct of proximal Segment IV. ABC immunohistochemistry. a. Bright field image. b. Nomarski image. Three vacuoles are seen; Two vacuoles contain immunoreactive material (arrowheads), but another vacuole shows no immunoreaction (asterisk). $\times 600$

Fig. 3. Electron micrographs showing vacuoles in the peculiar pale epithelial cells $(P)$ from Segment III. The vacuoles are situated in the cells. Microvilli are seen on the inner surface of the vacuoles, which frequently contain flocculent (asterisks) and amorphous (arrow) substances (a). Sometimes two vacuoles are found fused together in a cell (b). $B$ basal cell, $B L$ basal lamina, $P C$ principal cell. a: $\times 4,600$, b: $\times 5,640$ 


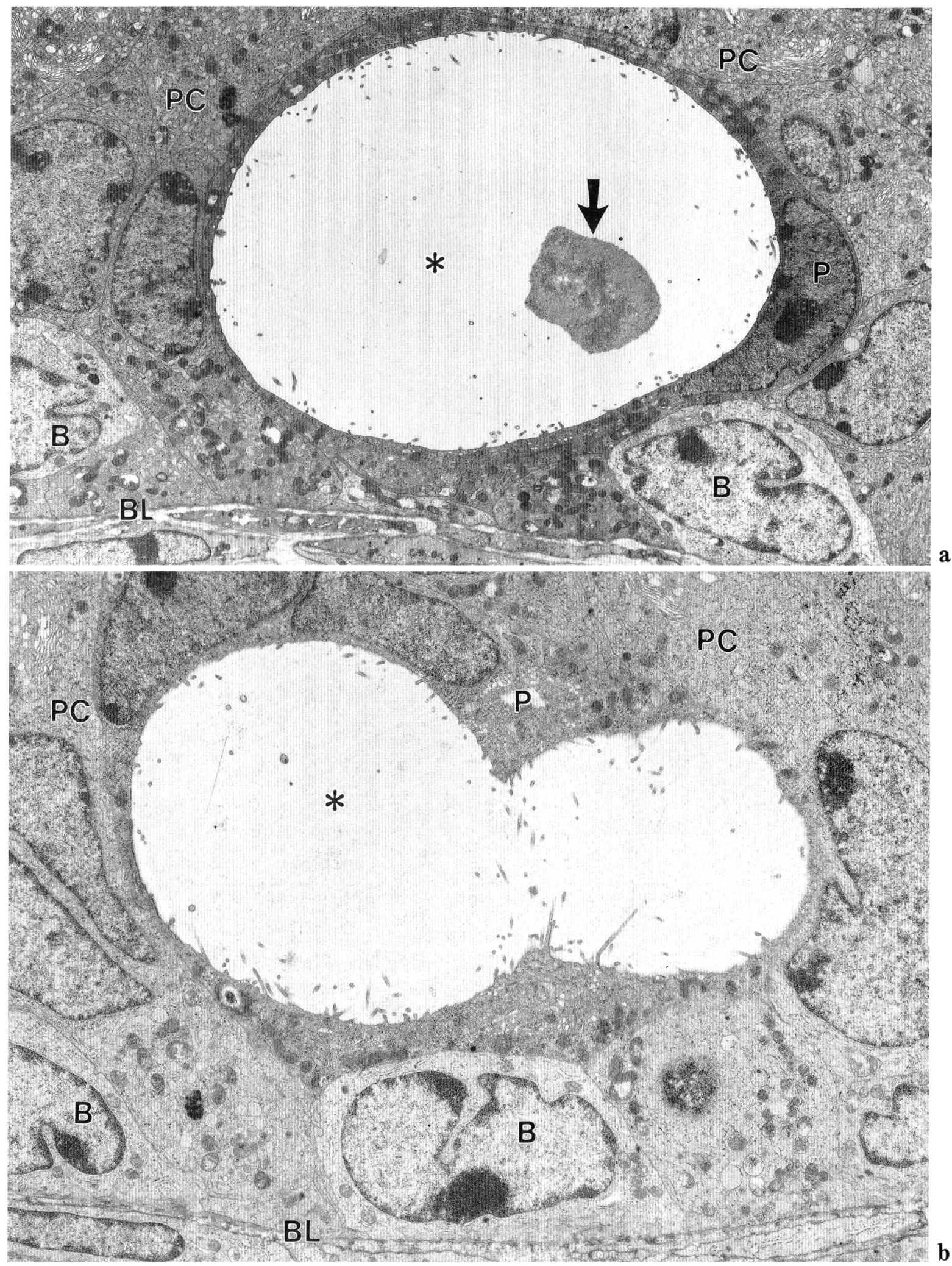

Fig. 3. Legend on the opposite page. 
sections were cut. In some cases, $2 \mu \mathrm{m}$ sections were cut, and stained with toluidine blue to detect intraepithelial vacuoles. Some sections representing the vacuoles were dehydrated in ethanol, and reembedded in Epon 812 to make ultrathin sections. The ultrathin sections were stained with uranyl acetate and lead citrate with a model 2168 AutoStainer (LKB-Produkter AB, Bromma, Sweden), and observed with a JEOL 200CX electron microscope.

\section{RESULTS}

IIF and $A B C$ immunohistochemistry revealed that luminal spermatozoa along the duct were first stained at Segment III, and the spermatozoa gradually increased in staining intensity during passage through Segment IV, with the staining intensity reaching its maximum in distal Segment IV or Segment V. The brush border (microvilli or stereocilia) also increased in immunostaining intensity in Segment III and Segment IV, while the immunostaining intensity decreased in Segment V. The immunoreactive materials appeared to be accumulated between and on the microvilli of the principal cells, but not in the microvilli. Immunoreaction was not detected in the cytoplasm of the normal principal cells throughout the epididymis, but a weak immunoreaction was found in the apical region of some clear cells in Segment IV. These findings have been previously reported (TosHIMORI et al., 1988, 1990).

In this study we paid particular attention to the unusual epithelial cells with vacuoles immunoreacting to T21 antibody (Figs. 1, 2). Such unusual cells occurred scattered or sometimes clustered (Figs. 1-3). In general, the vacuoles were round or oval in shape and present singly in a cell (Figs. 1-3a). The diameter of the vacuoles was usually upto $20 \mu \mathrm{m}$. Sometimes two vacuoles were found fused in a cell (Fig. $3 \mathrm{~b}$ ). The immunoreactive vacuoles were first detected in Segment III, where SGP54 was first detected, and the luminal spermatozoa were weakly or not stained (Fig. 2). In the distal Segment IV and Segment V, the immunoreactive vacuoles were always present, if rarely encountered. As such, the frequency of the immunoreactive vacuoles showed regional differences along the duct.

Although the immunostaining intensity of the vacuoles was usually strong, some vacuoles showed a weaker staining or none at all (Fig. 2). It was difficult to estimate the frequency of such unstained vacuoles, because small, unstained vacuoles could be overlooked. Our impression was that this frequency would be low.

Electron microscopic observation revealed that the unusual epithelial cells were encircled by normal epididymal constituent cells: principal cells, clear cells and basal cells (Fig. 3). The vacuoles were situated in the unusual epithelial cells, and microvilli were protruded into the vacuoles (Fig. 3). The unusual epithelial cells showing an immunoreaction contained aqueous and flocculent materials (Fig. 3). These materials appeared to account for the immunoreaction. The nucleus of the unusual epithelial cell was usually compressed laterally due to the vacuole, displaying a crescent shape (Fig. 3). The nuclear region was thick, while the other part of the cytoplasm was thin with a small amount of well developed rough endoplasmic reticulum and mitochondria (Fig. 3).

\section{DISCUSSION}

The unusual epithelial cells with vacuoles containing a specific epididymal glycoprotein SGP54, which were observed in this study, are morphologically identical to the peculiar pale epithelial cells (pale cells) reported by ABE et al. (1984). The pale cells are considered to originate from the basal cells and to have failed to differentiate into principal cells (ABE et al., 1984). It has also been reported that the caput epididymal secretory product (periodic acid-Sciff positve material) influences the principal cell differentiation, based on the results that the pale cells increased in number in Segment IV after the ligation at the junction between Segment III and Segment IV (ABE et al., 1982a,b, 1983, 1984). The present study clearly indicates that the pale cells occur in the corpus epididymidis even in normal conditions.

The epithelial cells of the distal caput epididymidis can produce and secrete SGP54 into the epididymal lumen (TOSHIMORI et al., 1988, 1990), although we have not succeeded in identifying the SGP54producing cell by any immunohistochemical techniques using T21. This failure is probably due to the strong masking of the epitope by sialyl residues, i.e., cryptodeterminant, as shown in our recent biochemical data; the epitope is postulated to be on the carbohydrate chain of the SGP54 molecule and strongly masked by sialyl residues when SGP 54 is fully sialylated, while the epitope is less masked when SGP54 is desialylated (ToshIMORI et al., 1990). The masking of the epitope by sialyl residues has been reported in mammalian spermatozoa (CZUPPON, 1984), and is well known in leukocytes, erythrocytes, syncytial trophoblast cells and some types of cancer cells (KELM et al., 1986; SCHAUER, 1985, 1987 for review).

Some vacuoles showed either weak or no immunostaining. Such a variety of immunostaining intensity presumably reflects the degree of masking of the 
epitope in addition to the condensation of SGP54; this also means partial degradation of the SGP54 molecule. The vacuoles that contain fresh, fully sialylated SGP54 show weak or no immunoreactivity, while the vacuoles that contain desialylated (or degraded) SGP54 show a strong immunoreaction due to unmasking. Our immunohistochemical data support this hypothesis; the fresh spermatozoa from the corpus epididymidis are effectively masked by fully sialylated SGP54, showing an intermittent staining pattern on the sperm cell surface, while neuraminidase-treated corpus spermatozoa or dead spermatozoa (typically headless spermatozoa) constantly showed a strong, linear staining pattern on the cell surface, on which the majority of SGP54 are desialylated by enzyme treatment or aging (TOSHIMORI et al., 1988, 1990 and unpublished data). In Segment III, regardless of whether the vacuole in the pale cells showed strong immunoreaction, luminal spermatozoa and fluid of the same region did not show immunoreaction. This can be also interpreted by the cryptodeterminant hypothesis: the content of the vacuoles contains desialylated SGP54 due to partial degradation during storage, while luminal spermatozoa and fluid have fresh, fully sialylated SGP54.

Acknowledgments. The authors are grateful to $\mathrm{Mr}$. Yoshiteru GOTO, and Mr. Yasunori FUJII for their technical assistance, and Miss Hiroko KIYOTAKE for preparing the manuscript.

\section{REFERENCES}

ABE, K., H. TAKano and T. ITo: Appearance of peculiar epithelial cells in the epididymal duct of the mouse ligated epididymis. Biol. Reprod. 26: 501-509 (1982a).

- : Response of the epididymal duct in the corpus epididymidis to efferent or epididymal duct ligation in the mouse. J. Reprod. Fert. 64: 69-72 (1982b).

- Response of epididymal duct to the temporary depletion of spermatozoa induced by testicular irradiation in mice. Anat. Rec. 207: 17-24 (1983).

- Interruption of the luminal flow in the epididymal duct of the corpus epididymidis in the mouse with special reference to differentiation of the epididymal epithelium. Arch. Histol. Jap. 47: 137-147 (1984).

AcotT, T. S. and D. D. Hoskins: Bovine sperm forward motility protein: Partial purification and characterization. J. Biol. Chem. 253: 6744-6750 (1978).

BEDFORD, J. M.: Maturation, transport and fate of spermatozoa in the epididymis. In: (ed. by) R. D. GREEP and E. B. Astwood: Handbook of physiology, Sec. 7, Vol. 3. Male reproduction. American Physiological Society, Washington, D. C., 1975 (p. 303-317).
Brooks, D. E.: Selective binding of specific rat epididymal secretory proteins to spermatozoa and erythrocytes. Gamete Res. 4: 367-376 (1983).

Czuppon, A. M.: Biochemical characterization of a human spermatozoal sialoglycoprotein with respect to antigenicity masking by its sialic acid moieties. Biochem. Int. 8: 9-18 (1984).

Flickinger, C. J.: Regional differences in synthesis, intracellular transport, and secretion of protein in the mouse epididymis. Biol. Reprod. 25: 871-883 (1981).

ISAHAKIA, M. A.: Monoclonal antibody localization of sperm surface antigen secreted by the epididymis of the baboon (Papio cynocephalus). J. Reprod. Fert. 86: 51-58 (1989).

JoNEs, R. C.: Changes in protein composition of the luminal fluids along the epididymis of the tammar, Macropus euganii. J. Reprod. Fert. 80: 193-199 (1987).

Kelm, S., A. K. Shukla, J. C. Paulson and R. Schauer: Reconstitution of the masking effect of sialic acid groups on sialidase-treated erythrocytes by the action of sialyltransferases. Carbohydr. Res. 149: 59-64 (1986).

Kuinefelter, G. R. and D. W. Hamilton: Synthesis and secretion of proteins by perifused caput epididymal tubules, and association of secreted proteins with spermatozoa. Biol. Reprod. 33: 1017-1027 (1985).

Kopecny, V., J. E. Flechon and J. Pivko: Binding of secreted glycoproteins to spermatozoa in the mammalian epididymis: A fine-structure autoradiographic study. Anat. Rec. 208: 197-206 (1984).

Moore, H. D. M. and T. D. Hartman: In-vitro development of the fertilizing ability of hamster epididymal spermatozoa after co-culture with epithelium from the proximal cauda epididymidis. J. Reprod. Fert. 78: 347352 (1986).

Moore, H. D. M., T. D. Hartman and C. A. Smith : In-vitro culture of hamster epididymal epithelium and induction of sperm motility. J. Reprod. Fert. 78: 327-336 (1986).

Olson, G. E. and M. C. Orgebin-Crist: Sperm surface changes during epididymal maturation. Ann. NY Acad. Sci. 383: 372-391 (1982).

Orgebin-Crist, M. C.: Sperm maturation in rabbit epididymis. Nature 216: 816-818 (1967).

- : Endocrine control of the development and maintenance of sperm fertilizing ability in the epididymis. In: (ed. by) R. O. GREEP and D. W. HAMILTON: Handbook of physiology, Vol. 5, Sect. 7, Endocrinology. American Physiological Society, Washington D. C., 1975 (p. 319-338).

Robaire, R. and L. Hermo: Efferent ducts, epididymis, and vas deferens: structure, functions, and their regulation. In: (ed. by) E. KNOBIL, J. NeILL et al.: The physiology of reproduction. Vol. 1, Chapter 2, Raven Press, New York, 1988 (p. 27-68).

Schauer, R.: Sialic acids and their role as biological masks. TIBS 10: 357-360 (1985).

-: Biochemistry of sialic acids. Seikagaku 59: 133-146 (1987). 
Smith, C. A., T. D. Hartman and H. D. M. Moore: A determinant of $\mathrm{M}_{\mathrm{r}} 34000$ expressed by hamster epididymal epithelium binds specifically to spermatozoa in co-culture. J. Reprod. Fert. 78: 337-345 (1986).

TAKANo, H.: Qualitative and quantitative histology and histogenesis of the mouse epididymis, with special emphasis on the regional difference. Acta Anat. Nippon. 55: 573-587 (1980).

Toshimori, K. and E. M. EdDY: Mouse sperm surface maturation antigens of $54 \mathrm{kd}$ and $34 \mathrm{kd}$ recognized by a monoclonal antibody. J. Cell Biol. 101: 363a (1985).

Toshimori, K., S. ARAKI and C. ŌURa: Masking of sperm maturation antigen by sialic acid in the epididymis of the mouse. An immunohistochemical study. Histochemistry 90: 195-200 (1988).

: Cryptodeterminant of a sperm maturation antigen on the mouse flagellar surface. Biol. Reprod. 42: 151-160 (1990).

Voglmayr, J. K., G. Fairbanks, M. A. Jackowitz and J.

R. Colella: Post-testicular developmental changes in the ram sperm cell surface and their relationship to luminal fluid proteins of the reproductive tract. Biol. Reprod. 22: 655-667 (1980).
Voglmayr, J. K., R. F. SAwYer Jr., and J. L. DacheuX: Glycoproteins: A variable factor in surface transformation of ram spermatozoa during epididymal transit. Biol. Reprod. 33: 165-176 (1985).

Dr. Kiyotaka TosHIMORI Department of Anatomy Miyazaki Medical College Kiyotake, Miyazaki 889-16 Japan

年 森 清 隆 889-16 宮崎県宮崎郡清武町木原 宮崎医科大学 第一解剖学教室 